\title{
Pengaturan Dan Penerapan Mitigasi Risiko Dalam Penyelenggaraan Peer To Peer Lending Guna Mencegah Pinjaman Bermasalah
}

\author{
Inda Rahadiyan dan M. Hawin \\ Fakultas Hukum Universitas Islam Indonesia \\ Fakultas Hukum Universitas Gadjah Mada \\ Jln. Tamansiswa No.158 Yogyakarta, Jln. Socio Justisia No.1 Bulaksumur \\ indarahadiyan1@gmail.com; hawin@mail.ugm.ac.id
}

Received: 23 Januari 2020; Accepted: 10 Mei 2020; Published: 25 Agustus 2020

DOI: 10.20885/iustum.vol27.iss2.art4

\begin{abstract}
Public interest in financial technology in the form of peer-to-peer lending (P2PL) is growing rapidly as an alternative provider of loans. In addition, it is a promising investment platform. The process of lending and borrowing between the lender and the recipient of the loan takes place through a system provided and managed by the organizing company that it provides various conveniences. However, the implementation of P2PL is also inseparable from the occurrence of non-performing loans. Regulating and implementing the risk mitigation of non-performing loans is an important issue in the implementation of P2PL. So far, there is no specific regulation regarding risk mitigation of P2PL implementation for non-performing loans, which results in weak legal certainty and protection for lenders. Therefore, the problems examined in this study include: First, how is the risk mitigation arrangement for non-performing loans in the implementation of P2PL in Indonesia? Second, how is the implementation of risk mitigation by the companies that carry out P2PL as an effort to prevent non-performing loans? This research is a normative legal research with a statutory and a conceptual approach. The results of the study concluded that: first, the P2PL risk mitigation arrangements, especially the risk of non-performing loans in Indonesia, are still scattered in several Financial Services Authority regulations and Bank Indonesia regulations. Second, the organizing company implements non-performing loan risk mitigation based on their respective internal policies.
\end{abstract}

Key Words: Risk mitigation; peer-to-peer lending; non-performing loan

\section{Abstrak}

Minat masyarakat pada financial technologi jenis peer-to-peer lending (P2PL) berkembang pesat sebagai alternatif penyedia pinjaman.Selain itu, merupakan wadah investasi yang cukup menjanjikan. Proses pinjammeminjam antara pemberi pinjaman dengan penerima pinjaman terjadi melalui sistem yang disediakan dan dikelola oleh perusahaan penyelenggara sehingga memberikan berbagai kemudahan. Akan tetapi, penyelenggaraan P2PL juga tidak terlepas dari terjadinya pinjaman bermasalah (Non-Performing Loan). Pengaturan dan penerapan mitigasi risiko pinjaman bermasalah merupakan persoalan penting di dalam penyelenggaraan P2PL. Sejauh ini regulasi yang mengatur khusus tentang mitigasi risiko penyelenggaraan P2PL terhadap pinjaman bermasalah belum ada, sehingga menimbulkan lemahnya kepastian dan perlindungan hukum bagi pemberi pinjaman. Oleh karena itu permasalahan yang dikaji dalam penelitian ini meliputi: Pertama, bagaimana pengaturan mitigasi risiko pinjaman bermasalah dalam penyelenggaraan P2PLdi Indonesia? Kedua, bagaimana penerapan mitigasi risiko oleh perusahaan penyelenggara P2PL sebagai upaya pencegahan terjadinya pinjaman bermasalah? Penelitian ini merupakan penelitian hukum normatif dengan pendekatan perundang-undangan serta pendekatan konseptual. Hasil penelitian menyimpulkan bahwa: pertama, pengaturan mitigasi risiko P2PL khususnya terhadap risiko pinjaman bermasalah di Indonesia masih tersebar dalam beberapa peraturan Otoritas Jasa Keuangan dan peraturan Bank Indonesia. Kedua, perusahaan penyelenggara menerapkan mitigasi risiko pinjaman bermasalah berdasarkan pada kebijakan internal masing-masing.

Kata-kata Kunci: Mitigasi risiko; peer-to-peer lending; pinjaman bermasalah 


\section{Pendahuluan}

Fenomena disruptive innovation yang mendorong perkembangan Financial Technology (fintech) telah mengubah landscape industri jasa keuangan secara komprehensif. Perubahan ini meliputi struktur industri, teknologi intermediasi serta mekanisme distribusi. ${ }^{1}$ Sebagaimana fenomena universal, fintech juga berkembang signifikan di Indonesia. Sektor fintech lending mengalami peningkatan hingga 274 persen pada Juni 2019.2 Per-November 2019, pelaku fintech lending mencapai 144 dengan komposisi 119 fintech lending konvensional berstatus terdaftar dan 13 fintech lending konvensional berstatus memiliki izin, serta 12 fintech lending syariah yang telah terdaftar di Otoritas Jasa Keuangan $(\mathrm{OJK}) .^{3}$

Secara konseptual istilah Fintech mengacu pada penggunaan teknologi sebagai suatu cara dalam mengatasi permasalahan-permasalahan keuangan. ${ }^{4}$ Dalam pengertian yang lebih spesifik, fintech diartikan sebagai pemanfaatan aplikasi-aplikasi digital dalam rangka mengatasi persoalan-persoalan intermediasi keuangan. ${ }^{5}$ Selain kedua pengertian tersebut, pengertian fntech juga merujuk pada inovasi teknologi dalam layanan jasa keuangan yang mampu menghasilkan berbagai model bisnis, aplikasi, proses atau produk-produk dengan efek material berkaitan dengan layanan keuangan. ${ }^{6}$

\footnotetext{
${ }^{1}$ Inda Rahadiyan, “Aspek Hukum dan Tantangan Pengaturan Peer to Peer Lending di Indonesia”, Materi Presentasi Seminar Nasional "Implementasi dan Tantangan Fintech Lending di Indonesia", diselenggarakan atas kerjasama Otoritas Jasa Keuangan Republik Indonesia dan Business Law Community Fakultas Hukum Universitas Gadjah Mada, 22 September 2018.

2Minat Fintech Melesat Akibat Lemahnya Perbankan,https://finansial.bisnis.com/read/20190724/89/ 1127973/minat-fintech-melesat-akibat-lemahnya-perbankan, diakses pada 15 Januari 2020.

3OJK, "Statisik Fintech Lending Periode November 2019”, https://www.ojk.go.id/id/kanal/iknb/datadan-statistik/fintech/Pages/Statistik-Fintech-Lending-Periode-November-2019.aspx diakses pada 10 Januari 2020. Sesuai dengan Pasal 8 POJK 77/POJK.01/2016, Penyelenggara yang akan melakukan kegiatan fintech wajib mengajukan permohonan pendaftaran ke OJK untuk memperoleh surat tanda bukti terdaftar dengan Status Terdaftar. Sedangkan pada Pasal 10 POJK 77/POJK.01/2016, setelah memperoleh Status Terdaftar, dalam jangka maksimal 1(satu) tahun sejak terdaftar di OJK, Penyelenggara wajib mengajukan permohonan izin.

4 Arner, D.W., Barberis, J., and Buckley, R.P,The Evolution of FinTech: A New Post-Crises Paradigm?, 2015, University of Hongkong, hlm. 32.

${ }^{5}$ Financial Technology (fintech) refers to technology-enabled fiancial solutions. The term FinTech is not confied to specifi sectors (e.g. fiancing) or business models (e.g. peer-to-peer (P2P) lending), but instead covers the entire scope of services and products traditionally provided by the fiancial services industry. Uraian lebih mendalam baca: M.Aaron, F. Rivadeneyra, dan S. Sohal, "Fintech: Is this time different? A framework for Assessing Risks and Opportunities for Central Banks", Bank of Canada Staff Discussion Paper 2017-10, July 2017. Baca pula: Muliaman D. Hadad, "Financial Technology di Indonesia", Presentasi Kuliah Umum tentang Fintecht, IBS, 2017, http://www.ibs.ac.id/img/ doc/MDH\%20-\%20FinTech\%20IBS\%20June\%202017.pdfdiakses pada 10 September 2019

${ }^{6}$ Muhammad Afdi Nizar, "Teknologi Keuangan (Fintech): Konsep dan Implementasinya Di Indonesia", Warta Fiskal Kementrian Kenangan Republik. Indonesia, Edisi 5, 2017, hlm. 6
} 
Terdapat berbagai jenis layanan fintech yang dikenal di dalam praktik. Jenisjenis layanan fintech dimaksud, masuk ke dalam beberapa kategori bidang jasa yang meliputi; pembayaran dan transfer, pinjaman dan pembiayaan, bank retail, manajemen keuangan serta jual-beli mata uang. ${ }^{7}$ Laporan penelitian Australian Centre for Financial Studies pada 2016 menyebutkan bahwa jenis fintech yang paling banyak digunakan di Indonesia adalah Peer to Peer Lending (P2PL). ${ }^{8}$

Secara umum, P2PL dapat didefinisikan sebagai setiap transaksi yang diatur dengan menggunakan internet yang memberikan pinjaman dari satu atau beberapa pihak individu kepada satu atau beberapa pihak individu yang lain. ${ }^{9}$ P2PL juga dimaknai sebagai 'financial exchange' yang terjadi langsung antara individu tanpa menggunakan lembaga intermediasi keuangan tradisional. ${ }^{10}$

Platform pinjaman P2PL muncul dengan berbagai kemudahan yang ditawarkan. Mekanisme pinjaman P2PL lebih mudah diakses oleh masyarakat pengguna. Penyelenggara P2PL menawarkan pinjaman dengan berbagai variasi saldo pokok, suku bunga, dan periode pembayaran. ${ }^{11}$ Kemudahan-kemudahan inilah yang kemudian berhasil menarik minat masyarakat untuk mengakses pinjaman melalui penyelenggara P2PL.

Apabila dibandingkan dengan fasilitas kredit perbankan, terdapat perbedaan mendasar antara kredit bank dengan pinjaman melalui mekanisme P2PL. Perbedaan tersebut terletak pada subjek hukum yang terlibat dan mekanisme penyaluran dana. Perjanjian kredit bank dilakukan oleh bank selaku kreditor dengan nasabah peminjam selaku debitor. Sementara itu, mekanisme

\footnotetext{
7 Uraian mengenai ini baca: Kevin David, et.all, "Catching-Up with Indonesia's Fintech Industry", Working Paper, Australian Centre for Financial Studies Monash Univesity, May 2017, https://australiancentre.com.au/wp-content/uploads/2017/05/2_Catching-Up-with-Indonesias-FintechIndustry.pdf

8 Kieran Garvey, et.all., "Laporan Industri Keuangan Alternatif Asia-Pasifik Ke-2: Meningkatkan Pertumbuhan", The Australian Centre for Financial Studies Monash University bekerja sama dengan Cambridge Centre for Alternative Finance dan Tsinghua University, https://australiancentre.com.au/wpcontent/uploads/2017/09/APAC_BH_e.pdf

${ }^{9}$ Eric C. Chaffee dan Geoffrey C. Rapp, "Regulating Online Peer-to-Peer Lending in the Aftermath of Dodd-Frank: In Search of an Evolving Regulatory Regime for an Evolving Industry", Washington and Lee Review, Vol.69, Issue 2, Article 4, 2012, h.493.

${ }^{10}$ Eugenia Omarini, "A Peer-to-Peer Lending: Business Model Analysis and the Platform Dilemma", International Journal of Finance, Economics, and Trade (IJFET), Research Article, 2(3), 2018, hlm. 31 diakses melalui https://www.semanticscholar.org/paper/Peer-to-peer-lending\%3A-business-model-analysis-and-Omarini/ e20dcad9663332f271397ec0471caf329130514c diakses pada 18 Januari 2020.

${ }^{11}$ Andrew Verstein, "The Misregulation of Person-to-Person Lending”, University of California, Davis, Vo. 45, 445, 2011, hlm. 463.
} 
P2PL melibatkan tiga pihak yakni investor selaku kreditor, peminjam selaku debitor serta perusahaan penyelenggara selaku pihak yang menyediakan dan mengelola market place (teknologi yang mempertemukan kreditor dengan debitor).

Berdasarkan data OJK, hingga Desember 2019, terdapat 164 perusahaan fintech dengan komposisi sebagai berikut: 139 perusahaan terdaftar dan 25 perusahaan berizin; 152 perusahaan tersebut bergerak menggunakan sistem konvensional, sedangkan 12 perusahaan lainnya menggunakan prinsip syariah. Akumulasi rekening pemberi pinjaman per-Desember 2019 sejumlah 605.935 entitas. Sedangkan, akumulasi rekening peminjam berjumlah 18.569 .123 entitas. ${ }^{12}$

Perkembangan P2PL yang sangat pesat di Indonesia kemudian diikuti dengan upaya pengaturan oleh OJK dan Bank Indonesia selaku regulator dan pengawas. ${ }^{13}$ Upaya pengaturan terhadap industri fintech telah dilakukan oleh kedua otoritas melalui penerbitan berbagai peraturan. Peraturan-peraturan dimaksud yakni; (1) Peraturan Otoritas Jasa Keuangan Nomor 77/POJK.01/2016 tentang Pinjam Meminjam Uang Berbasis Teknologi Informasi (POJK No. 77/POJK.01/2016), (2) Peraturan Otoritas Jasa Keuangan Nomor 13/POJK.02/2018 tentang Inovasi Keuangan Digital di Sektor Jasa Keuangan (POJK No. 13/POJK.02/2018, serta (3) Peraturan Bank Indonesia Nomor 19/12/PBI/2017 tentang Penyelenggaraan Teknologi Finansial (PBI No. 19/12/PBI/2017). ${ }^{14}$ Dari ketiga peraturan dimaksud, peraturan yang secara khusus mengatur P2PL yakni POJK No. 77/POJK.01/2016.

Berdasarkan data OJK, jumlah perusahaan penyelenggara fintech P2PL yang telah terdaftar dan memperoleh izin resmi berjumlah 144 perusahaan per 30

12 OJK, "Perkembangan Fintech Lending Periode Deseber 2019", https://www.ojk.go.id/id/ $\mathrm{kanal} / \mathrm{iknb} / \mathrm{data}-\mathrm{dan}$-statistik/fintech/Pages/Statistik-Fintech-Lending-Periode-Desember-2019.aspx diakses pada 13 April 2020.

${ }^{13}$ Tugas, fungsi dan wewenang pengaturan dan pengawasan industri jasa keuangan perbankan secara resmi beralih dari Bank Indonesia kepada OJK sesuai dengan amanah Pasal 34 Undang-Undang Nomor 3 Tahun 2004 tentang Perubahan atas Undang-Undang Nomor 23 Tahun 1999 tentang Bank Indonesia. Sementara itu, Bank Indonesia tetap memegang tugas, fungsi dan wewenang pengawasan pada aspek makro. Hal demikian sebagaimana diatur dalam Undang-Undang Nomor 21 Tahun 2011 tentang Otoritas Jasa Keuangan.

${ }^{14}$ Hendrikus Passagi, "Fintech Lending Indonesia Pendanaan Gotong Royong Online", Materi Seminar Nasional "Implementasi dan Tantangan Fintech Lending di Indonesia", Kerjasama antara Business Law Community Fakultas Hukum UGM dengan Otoritas Jasa Keuangan Republik Indonesia, Yogyakarta 22 September 2018. 
Oktober 2019.15 Jumlah tersebut mengalami peningkatan signifikan dibandingkan jumlah perusahaan terdaftar dan berizin per Desember 2018 yang berjumlah 88 perusahaan. ${ }^{16}$ Apabila mencermati jumlah dimaksud, tren pertumbuhan perusahaan penyelenggara Fintech P2PL mengalami peningkatan hampir dua kali lipat dalam kurun waktu satu tahun.

Pertumbuhan jumlah perusahaan penyelenggara Fintech P2PL juga diikuti dengan peningkatan jumlah penyaluran dana pinjaman. Akumulasi jumlah pinjaman yang telah disalurkan oleh penyelenggara mencapai Rp. 22.600.000.000.000,00 per Desember 2018.17 Akumulasi jumlah pinjaman meningkat menjadi Rp. 74.500.000.000.000,00 per November 2019.18 Jumlah total pinjaman yang disalurkan oleh penyelenggara mengalami peningkatan lebih dari 300 persen dalam kurun waktu 2018 hingga 2019.

Perkembangan jumlah penyaluran dana melalui mekanisme P2PL tersebut pada kenyataanya tidak terlepas dari risiko pinjaman bermasalah (Non-Performing Loan). ${ }^{19}$ Per Desember 2018 OJK mencatat bahwa Non Performing Loan (NPL) P2PL berada pada angka 3.30\% untuk pinjaman tidak lancar dan 1.45\% untuk pinjaman macet. $^{20}$ Pada Desember 2019, NPL mencapai 3.65\%. ${ }^{21}$ Angka demikian

15 Perusahaan Fintech Lending Terdaftar dan Berizin di OJK per 30 Oktober 2019. Data diakses dari laman https://ojk.go.id/id/berita-dan-kegiatan/publikasi/Pages/Penyelenggara-Fintech-Terdaftar-dan-Berizindi-OJK-per-30-Oktober-2019.aspx. Data diakses pada tanggal 20 Desember 2019, pukul 09.29 WIB.

16 Perusahaan Fintech Lending Terdaftar dan Berizin di OJK per Desember 2018. Data diakses dari laman https://www.ojk.go.id/id/berita-dan-kegiatan/publikasi/Pages/Penyelenggara-Fintech-Terdaftar-diOJK-per-Desember-2018.aspx. Data diakses pada tanggal 20 Desember 2019, pukul 09.35 WIB.

17 Ikhtisar Data Keuangan Fintech (Peer To Peer Lending) Periode Desember 2018. Data diakses dari laman: https://www.ojk.go.id/id/kanal/iknb/data-dan-statistik/fintech/Pages/Ikhtisar-Data-Keuangan-Fintech-(PeerTo-Peer-Lending)-Periode-Desember-2018.aspx. Data diakses pada tanggal 25 Februari 2019 pada pukul 10.20 WIB.

${ }^{18}$ Statistik Fintech Lending Periode November 2019. Data diakses dari laman: https://www.ojk.go.id/id/ $\mathrm{kanal} / \mathrm{iknb} /$ data-dan-statistik/fintech/Pages/Statistik-Fintech-Lending-Periode-November-2019.aspx. Data diakses pada tanggal 7 Januari 2020 pada pukul 08.30 WIB.

${ }^{19}$ Rasio Non Performing Loan (NPL) merupakan rasio untuk mengukur kemampuan manejemen bank dalam mengatasi kredit bermasalah. Non Performing Loan (NPL) diukur dari perbandingan antara kredit bermasalah terhadap total kredit. Terdapat tiga kelompok kolektibilitas yang merupakan kredit bermasalah atau NPL, yakni; (1) Kredit kurang lancar, (2) kredit diragukan, (3) kredit macet. Ketentuan lebih lanjut mengenai NPL baca:Peraturan Bank Indonesia Nomor 15/2/PBI/2013 tentang Penetapan Status dan Tindak Lanjut Pengawasan Bank Umum Konvensional.

${ }^{20}$ Ikhtisar Keuangan Fintech Peer to Peer Lending Periode Desember 2018, https://www.ojk.go.id/id/ $\mathrm{kanal} / \mathrm{iknb} /$ data-dan-statistik/fintech/Pages/Ikhtisar-Data-Keuangan-Fintech-(Peer-To-Peer-Lending)-PeriodeDesember-2018.aspx. Mengenai ini antara lain baca juga: "Kredit Macet Fintech Meningkat", http:/ / www.neraca.co.id/article/97995/fintech-mirip-rentenir-era-digital-ojk-kredit-macet-fintech-meningkat, OJK Targetkan NPL Fintech Lending di bawah 1\%, https://keuangan.kontan.co.id/news/ojk-targetkan-nplfintech-lending-di-bawah-1-hingga-akhir-2018. 
cenderung tinggi apabila dibandingkan dengan target NPL fintech lending yang oleh OJK ditetapkan berada di bawah $1 \% .^{22}$

Mendasarkan pada fakta mengenai perkembangan jumlah penyaluran dana P2PL dan risiko NPL yang cenderung meningkat, maka perihal pengaturan dan penerapan mitigasi risiko guna mencegah pinjaman bermasalah dalam penyelenggaraan P2PL menjadi suatu hal yang penting dan relevan untuk dikaji. Hal ini mengingat belum diaturnya secara khusus mengenai mitigasi risiko penyelenggaraan Peer to Peer Lending terhadap pinjaman bermasalah. Kondisi demikian berpotensi menyebabkan lemahnya jaminan kepastian dan perlindungan hukum khususnya bagi pihak pemberi pinjaman.

\section{Rumusan Masalah}

Berdasarkan latar belakang di atas, maka rumusan masalah yang dikaji dalam penelitian ini adalah: pertama, bagaimana pengaturan mitigasi risiko pinjaman bermasalah dalam penyelenggaraan Peer to Peer Lending di Indonesia? Kedua, bagaimana penerapan mitigasi risiko oleh perusahaan penyelenggara Peer to Peer Lending sebagai upaya pencegahan terjadinya pinjaman bermasalah?

\section{Tujuan Penelitian}

Penelitian ini bertujuan untuk: pertama, mengetahui dan menganalisis pengaturan mitigasi risiko pinjaman bermasalah dalam mekanisme Peer to Peer Lending di Indonesia. Kedua, mengetahui dan menganalisis penerapan mitigasi risiko oleh perusahaan penyelenggara Peer to Peer Lending sebagai upaya pencegahan terjadinya pinjaman bermasalah.

${ }^{21}$ NPL dilihat dari Tingkat Keberhasilan 90 hari (TKB90). Pada Desember 2018 TKB mencapai 98,55\% sehingga pinjaman macet macet atau NPL 1.45\%, sedangkan Desember 2019, TKB90 menurun menjadi 96.35\% sehingga pinjaman macet naik 3.65\%. Statistik Fintech Lending Per Desember 2019, data dapat diakses melalui laman: https://www.ojk.go.id/id/kanal/iknb/data-dan-statistik/fintech/Pages/Statistik-Fintech-LendingPeriode-Desember-2019.aspx diakses pada 10 April 2020.

22 Rasio ini diberlakukan untuk semua jenis fintech lending, termasuk P2PL. Mengenai ini, antara lain baca: (1) "OJK akan Patok Tingkat Kredit Bermasalah Fintech Pendanaan 1 Persen", https://www.antaranews.com/berita/929228/ojk-akan-patok-tingkat-kredit-bermasalah-fintech-pendanaan-1persen. (2) "OJK Targetkan NPL Fintech Lending di Bawah 1\% Hingga Akhir 2018", https://keuangan.kontan.co.id/news/ojk-targetkan-npl-fintech-lending-di-bawah-1-hingga-akhir-2018. diakses pada 30 Juni 2019. 


\section{Metode Penelitian}

Jenis penelitian yang digunakan adalah penelitian hukum normatif. Penelitian hukum normatif dilakukan dengan mengkonsepsikan hukum sebagai norma yang meliputi nilai-nilai dan hukum positif. ${ }^{23}$ Pendekatan yang digunakan adalah pendekatan perundang-undangan dan pendekatan konseptual. Penulis mengkaji ketentuan perundang-undangan ${ }^{24}$ berdasarkan teori-teori hukum ${ }^{25}$, hasil kajian kemudian diterapkan pada permasalahan hukum yang terjadi di dalam praktek.

Pendekatan perundang-undangan dilakukan dengan menelaah dan mengkaji keseluruhan undang-undang dan regulasi yang saling terkait dengan isu hukum yang sedang diteliti. ${ }^{26}$ Pendekatan perundang-undangan dipergunakan untuk mempelajari konsistensi undang-undang dengan undangundang dasar maupun peraturan perundang-undangan yang lain sekaligus menjawab isu hukum. ${ }^{27}$ Pendekatan perundang-undangan yaitu pendekatan yang dilakukan untuk meneliti aturan perundang-undangan, dan berbagai aturan hukum yang menjadi fokus penelitian. ${ }^{28}$ Pada penelitian ini, perundangundangan yang menjadi acuan yaitu:

1. Undang-Undang Nomor 19 Tahun 2016 tentang Perubahan Atas UndangUndang Nomor 11 Tahun 2008 tentang Informasi dan Transaksi Elektronik

2. Peraturan Pemerintah Nomor 71 Tahun 2019 tentang Penyelenggaraan Sistem dan Transaksi Eletronik

3. Peraturan Otoritas Jasa Keuangan Nomor 77/POJK.01/2016 tentang Layanan Pinjam Meminjam Uang Berbasis Teknologi Informasi

4. Peraturan Otoritas Jasa Keuangan Nomor 18/POJK.03/2017 tentang Pelaporan dan Permintaan Informasi Debitor Melalui Sistem Layanan Informasi Keuangan

5. Peraturan Otoritas Jasa Keuangan Nomor 13/POJK.02/2018 tentang Inovasi Keuangan Digital di Sektor Jasa Keuangan

${ }^{23}$ Tim Penulisan Pedoman Tugas Akhir, Pedoman Penulisan Tugas Akhir Program Studi S1 Ilmu Hukum, ctk. Kedua, FH UII Press, Yogyakarta, 2016. hlm. 10.

${ }^{24}$ Peter Mahmud Marzuki, Penelitian Hukum, Kencana Prenada Media Group, Jakarta, 2017, hlm. 93.

${ }^{25}$ Ibid., hlm. 137

${ }^{26}$ Ibid., hlm. 133.

${ }^{27}$ Abdul Kadir Muhammad, Hukum dan Penelitian Hukum, PT. Citra Aditya Bakti, Bandung, 2004, hlm. 52 ${ }^{28}$ Ibid. 
6. Peraturan Bank Indonesia Nomor 19/12/PBI/2017 tentang Penyelenggaraan Teknologi Finansial

7. Lampiran IV Surat Edaran OJK Nomor 50/SEOJK.03/2017 tentang Pelaporan dan Permintaan Informasi Debitur Melalui Sistem Layanan Informasi Keuangan

Pendekatan konseptual merupakan pendekatan yang beranjak dari pandangan-pandangan dan doktrin-doktrin yang berkembang dalam ilmu hukum. ${ }^{29}$ Penelitian ini merujuk pada konsep mitigasi risiko dan konsep pinjaman bermasalah.

Teknik pengumpulan bahan hukum dalam penelitian ini adalah studi kepustakaan atau studi dokumen (library research). Analisis data dilakukan secara kualitatif sesuai dengan relevansinya terhadap permasalahan penelitian. Data yang telah dianalisis secara kualitatif kemudian disajikan ke dalam bentuk narasi deskriptif eksploratif dan argumentatif.

\section{Hasil Penelitian dan Pembahasan}

\section{Pengaturan Mitigasi Risiko Pinjaman Bermasalah dalam Penyelenggaraan Peer to Peer Lending di Indonesia}

Pelaksanaan P2PL melibatkan 3 pihak, yakni: Penyelenggara Layanan, Pemberi Pinjaman dan Penerima Pinjaman. ${ }^{30}$ Dari ketiga pihak tersebut maka timbullah hubungan hukum diantara ketiganya yang mana memiliki 2 (dua) macam hubungan hukum, yaitu: ${ }^{31}$

1. Hubungan hukum antara pemberi pinjaman dan penerima pinjaman yaitu hubungan perjanjian pinjam-meminjam yang diatur dalam Pasal 1754 KUHPerdata ${ }^{32}$.

2. Hubungan hukum antara penyelenggara dan pemberi pinjaman. Hubungan tersebut merupakan hubungan Perjanjian Pemberian Kuasa yang diatur pada Pasal 1792 KUHPerdata ${ }^{33}$.

\footnotetext{
${ }^{29}$ Ibid., hlm. 135. Angka 8 .

${ }^{30}$ Inda Rahadiyan, Op. Cit., Lihat pula POJK Nomor 77/POJK.01/2016 Pasal 1 Angka 6, Angka 7,

${ }^{31}$ Inda Rahadiyan, Ibid.

32 Pasal 1754 KUHPer berbunyi "Persetujuan dengan mana pihak yang satu memberikan jumlah tertentu barang-barang yang habis karene pemakaian, dengan syarat bahwa pihak yang terakhir ini akan mengembalikan sejumlah yang sama dengan jenis dan mutu yang sama pula."

33 Pasal 1792 KUHPer berbunyi "Pemberian Kuasa ialah suatu persetujuan yang berisikan pemberian kekuasaan kepada orang lain yang menerimanya untuk melaksanakan sesuatu atas nama orang yang memberikan kuasa."
} 
Kedua hubungan tersebut berdasarkan perjanjian yang dilaksanakan secara elektronik sebagai media untuk membuat perjanjian atau disebut sebagai kontak elektronik (Pasal 1 Angka 17 PP Nomor 71 Tahun 2019 tentang Penyelenggaraan Sistem dan Transaksi Elektronik). ${ }^{34}$ Adanya hubungan hukum antara Penyelenggara Layanan, Pemberi Pinjaman dan Penerima Pinjaman tentu akan menghasilkan risiko pula. Risiko dalam P2PL umumnya berupa pinjaman bermasalah. Oleh sebab itu diperlukan adanya mitigasi risiko untuk mencegah terjadinya risiko pinjaman bermasalah.

Menurut Black Law's Dictionary, mitigasi dapat dipadankan dengan kata 'mitigate' yakni " to make less severe or intense" 35 , sedangkan pengertian risiko atau 'risk' ialah the uncertainty of a result, happening, or loss. ${ }^{36}$ Dengan demikian, dapat dirumuskan bahwa mitigasi risiko dalam penelitian ini merujuk pada tindakan mencegah timbulnya kerugian.

Mitigasi risiko dalam P2PL mensyaratkan identifikasi, pengukuran, serta monitor dan kontrol risiko kredit dan risiko operasional yang muncul dari semua layanan fintech P2PL yang bertujuan untuk mencegah dan memitigasi risiko kredit dan risiko operasional. ${ }^{37}$ Mitigasi risiko adalah segala upaya yang dilakukan dalam rangka mencegah timbulnya berbagai risiko dalam penyelenggaraan P2PL Risiko yang menjadi fokus dalam penelitian ini yaitu risiko pinjaman bermasalah atau NPL.

P2PL menjadi alternatif investasi dan sumber pendanaan yang sangat praktis bagi masyarakat. Berinvestasi di P2PL cukup menjanjikan return bagi pemberi pinjaman (lender). ${ }^{38}$ Di sisi lain, penting untuk dipahami bahwa secara mendasar, pihak pemberi pinjaman sepenuhnya menanggung risiko pinjaman

\footnotetext{
34Pasal 1 Angka 17 PPNomor 71 Tahun 2019 tentang Penyelenggaraan Sistem dan Transaksi Elektronik berbunyi "Kontrak Elektronik adalah perjanjian para pihak yang dibuat melalui Sistem Elektronik". Hal ini mengingat P2PL merupakan transaksi yang dijalankan secara elektronik sehingga segala bentuk transaksi termasuk perjanjiannya melalui Sistem Elektronik. Lihat pula Pasal 5 Undang-Undang Nomor 19 Tahun 2016 Tentang Perubahan Atas Undang-Undang nomor 11 Tahun 2008 Tentang Informasi dan Transaksi Elektronik.

35 Bryan. A. Garner, Black's Law Dictionary, 8 ${ }^{\text {th }}$ Edition, Thomson Reuters, U.S. Gov, 2004, hlm. 3174.

${ }^{36}$ Ibid, hlm. 4135

37 Trisadini P.Usanti dan Fiska Silvia R.R, "Legal Protection of the Contracting Parties in The Peer to Peer Lending Based on Finacial Technology (P2P Lending Fintech) in Indonesia", Advances in Social Science, Education and Humanities Research (ASSEHR), Vol.131, Interntional Conference on Law, Governance and Globlzation 2017 (ICLGG 2017), Atlantis Press, hlm. 291.

${ }^{38}$ Darman, "Financial Technology (Fintech): Karakteristik dan Kualitas Pinjaman pada Peer to Peer Lending di Indonesia", Jurnal Manajemen Teknologi, Vol.18, No.2, 2019, hlm. 132.
} 
macet. Hal ini berbeda dari sistem kredit bank yang secara mendasar, risiko kredit macet menjadi beban pihak bank selaku pemberi pinjaman. Risiko paling besar yang harus ditanggung oleh pemberi pinjaman dalam P2PLadalah jika terjadi pinjaman macet (gagal bayar) oleh peminjam. ${ }^{39}$

Risiko kredit merupakan persoalan mendasar dalam industri P2PL saat ini. Dari perspektif makro, rendahnya hambatan masuk ke dalam industri P2PLpada level tertentu berpotensi menimbulkan risiko makro yang tidak terkendali. Sementara dari perspektif mikro, sebagian besar bisnis platform P2PL masih berada dalam masa pertumbuhan. ${ }^{40}$ Pengalaman operasional dan kemampuan manajemen risiko dari perusahaan penyelenggara pada umumnya belum memadai. Pinjaman macet tetap menjadi risiko besar yang dihadapi oleh industri P2PL pada masa depan. ${ }^{41}$ Pinjaman bermasalah tidak hanya menjadi risiko dalam penyelenggaraan P2PL, tetapi juga dalam penyaluran kredit bank.

Pengaturan mitigasi risiko P2PL termuat dalam BAB V POJK No.77/POJK.01/2016, khususnya pada Pasal 21 hingga 24. Pasal 21 POJK No.77/POJK.01/2016 mengatur kewajiban Penyelenggara dan Pengguna untuk melakukan mitigasi risiko. Penyelenggara adalah pihak berupa badan hukum yang menyediakan, mengelola, dan mengoperasikan layanan P2PL ${ }^{42}$, sedangkan Pengguna adalah pemberi pinjaman dan penerima pinjaman yang mengunakan layanan P2PL.43 Pasal 23 POJK No.77/POJK.01/2016 mengatur adanya kemungkinan bagi Penyelenggara untuk bekerjasama dan melakukan pertukaran data dengan penyelenggara layanan pendukung berbasis teknologi informasi dalam rangka peningkatan kualitas P2PL.

Pasal 24 mengatur kewajiban penyelenggara untuk menggunakan escrow account dan virtual account dalam rangka P2PL. Escrow account adalah rekening giro di bank atas nama Penyelenggara yang merupakan titipan dan digunakan untuk tujuan tertentu, yaitu penerimaan dan pengeluaran dana dari dan kepada

${ }^{39}$ Ibid.

${ }^{40}$ Jianhui Yang, et.al,"Research on P2P Credit Risk Assessment Model Based on RBM Feature Extraction- Take SME Customers as an Example", Open Journal of Business and Management, Scientific Research Publishing, Agustus, 2019 , hlm. 1554, DOI: 10.4236/ojbm.2019.74107 diakses pada 15 Januari 2020.

${ }^{41}$ Ibid.

42 Pasal 1 Angka 6 POJK No.77/POJK.01/2016.

43 Pasal 1 Angka 9 POJK No.77/POJK.01/2016. 
pengguna jasa P2PL. ${ }^{44}$ Sementara itu, virtual account adalah layanan perbankan yang termasuk di dalam atau bagian dari escrow account. Virtual Account berupa nomor identifikasi pengguna jasa Penyelenggara (end user) dan dapat dibuat oleh Penyelenggara atau bank. Hal ini bertujuan untuk mengidentifikasi penerimaan dan pengeluaran dana dari dan/atau kepada suatu rekening. ${ }^{45}$ Penyelenggara wajib menyediakan virtual account bagi setiap Pemberi Pinjaman. Penerima Pinjaman melakukan pembayaran melalui escrow account Penyelenggara yang kemudian diteruskan ke virtual account Pemberi Pinjaman. ${ }^{46}$

Pasal 22 mengatur kemungkinan bagi Penyelenggara untuk menjadi anggota Sistem Layanan Informasi Keuangan (SLIK) OJK atau sistem layanan informasi lainnya yang terdaftar di OJK dengan memenuhi persyaratan sesuai dengan ketentuan peraturan perundang-undangan. SLIK adalah sistem informasi yang dikelola oleh OJK untuk mendukung pelaksanaan tugas pengawasan dan layanan informasi di bidang keuangan. ${ }^{47}$ Ketentuan tentang SLIK diatur secara khusus dalam POJK No.18/POJK.03/2017 tentang Pelaporan dan Permintaan Informasi Debitur Melalui Layanan Informasi Keuangan (POJK No.18/POJK.03/2017).

Pasal 3 ayat (1) POJK No.18/POJK.03/2017 mengatur tentang lembaga jasa keuangan lainnya yang menyediakan P2PL dan lembaga keuangan mikro dapat menjadi pelapor dengan mengajukan permohonan dan mendapat persetujuan OJK dengan memenuhi persyaratan sebagai berikut:

1. memiliki infrastruktur yang memadai;

2. memiliki data yang diperlukan dalam SLIK; dan

3. menandatangani perjanjian keikutsertaan dalam pelaporan dan permintaan informasi debitur melalui SLIK.

Syarat-syarat di atas bersifat kumulatif dan wajib dipenuhi oleh pelapor dalam sistem SLIK. Menurut Pasal 1 angka 8 POJK No.18/POJK.03/2017,pelapor

\footnotetext{
${ }^{44}$ Surat Edaran Otoritas Jasa Keuangan Nomor /SEOJK.05/2017 Tentang Penyelenggaraan Layanan Pinjam Meminjam Uang Berbasis Teknologi Informasi

${ }^{45}$ Ibid.

${ }^{46}$ Pasal 24 ayat (1) sampai ayat (4) POJK No 77/POJK.01/2016

${ }^{47}$ Pasal 1 angka 13 POJK No 18/POJK.03/2017 jo Lampiran IV Surat Edaran OJK Nomor 50/SEOJK.03/2017 tentang Pelaporan dan Permintaan Informasi Debitur Melalui Sistem Layanan Informasi Keuangan.
} 
adalah pihak yang melakukan pelaporan dan permintaan informasi debitur melalui Sistem Layanan Informasi Keuangan (SLIK) kepada OJK. Pelapor berkewajiban menyampaikan laporan debitur secara lengkap, akurat, terkini, utuh, dan tepat waktu setiap bulan untuk posisi akhir tahun kepada OJK.48 Laporan debitur tersebut wajib memuat informasi terkait debitur, fasilitas penyediaan dana, agunan, penjamin, pengurus dan pemilik, serta keuangan debitur. ${ }^{49}$ Laporan debitur yang dibuat oleh pelapor dapat diakses atau diminta oleh beberapa pihak antara lain Debitur, LPIP, 50 dan pihak lain. ${ }^{51}$

Pihak lain dimaksud adalah pihak yang berdasarkan peraturan perundangundangan dan/atau berdasarkan nota kesepahaman dengan OJK berwenang untuk memeroleh informasi debitur. Misalnya pemerintah pusat, pemerintah daerah, lembaga negara, Bank Indonesia, Lembaga Penjamin Simpanan (LPS), Pusat Pelaporan dan Analisis Transaksi Keuangan (PPATK), serta aparat penegak hukum dalam rangka pelaksanaan tugas dan wewenang berdasarkan peraturan perundang-undangan.52 Pihak-pihak yang termasuk dalam kategori pihak lain hanya dapat meminta informasi debitur yang berisi identitas debitur, pemilik dan pengurus bagi debitur badan usaha, fasilitas penyediaan dana yang diterima debitur, agunan, penjamin, kualitas fasilitas penyediaan dana, dan informasi lain berupa informasi keuangan debitur..$^{53}$

Pelapor SLIK dapat mengakses website SLIK yang memiliki fungsi untuk mengunggah berkas laporan, permintaan informasi debitur, pemantauan informasi debitur, pengelolaan pengguna, pemantauan aktivitas pengguna, dan koreksi data secara daring. Hal tersebut dapat dilakukan untuk mengetahui data terkait infomasi debitur yang mengajukan kredit pertama kali ataupun dalam masa peminjaman kredit oleh satu atau beberapa lembaga keuangan. ${ }^{54}$ Aplikasi SLIK terdiri dari tiga yaitu aplikasi SLIK Reporting, aplikasi SLIK Web, dan

${ }^{48}$ Pasal 4 ayat (1) POJK No 18/POJK.03/2017

${ }^{49}$ Pasal 4 ayat (2) POJK No 18/POJK.03/2017

50 LPIP adalah Lembaga Pengelola Informasi Perkreditan yang merupakan lembaga atau badan yang menghimpun dan mengolah data kredit dan data lain untuk menghasilkan informasi perkreditan sesuai dengan ketentuan peraturan perundang-undangan tentang LPIP (Pasal 1 Angka 14 POJK No.18/POJK.03/2017)

${ }^{51}$ Pasal 14 POJK No 18/POJK.03/2017

${ }^{52}$ Penjelasan Pasal 14 ayat (1) POJK No 18/POJK.03/2017

${ }^{53}$ Pasal 14 ayat (2) POJK No 18/POJK.03/2017

${ }^{54}$ Otoritas Jasa Keuangan, Pedoman Penyusunan Laporan Debitur Melalui Sistem Layanan Informasi Keuangan Versi 6, 2017. 
aplikasi iDeb Viewer. Aplikasi SLIK Reporting adalah aplikasi SLIK yang dipasang pada perangkat komputer Pelapor. Aplikasi tersebut berfungsi untuk validasi data, enkripsi, kompresi, dan pembentukan file laporan yang siap dikirim ke peladen (server) OJK. Selain itu, SLIK Reporting berfungsi untuk pengiriman Laporan Debitur langsung ke peladen (server) melalui File Transfer Protocol (FTP). 55

Aplikasi SLIK Web adalah aplikasi yang dipasang di OJK dan diakses oleh Pelapor menggunakan Web browser melalui jaringan komunikasi data yang ditetapkan oleh OJK. Aplikasi SLIK Web memiliki fungsi antara lain untuk mengunggahfile Laporan Debitur sebagai alternatif pengiriman laporan, pemantauan laporan, permintaan informasi debitur, pemantauan permintaan informasi debitur, koreksi data secara daring, pengelolaan pengguna, dan pemantauan aktivitas pengguna. ${ }^{56}$ Sedangkan aplikasi $i$ Deb Viewer adalah aplikasi yang dipasang di komputer Pelapor untuk menampilkan hasil permintaan informasi debitur dari aplikasi SLIK Web. ${ }^{57}$

Sistem pelaporan SLIK memberikan kemudahan dalam pelaksanaan analisa kredit. Dalam mekanisme kredit bank, analisa kelayakan calon debitor dilakukan berdasarkan analisis 5C dan 5P. Analisis 5C meliputi analisis kelayakan terhadap aspek Watak (Character), Kemampuan (Capacity), Modal (Capital), Kondisi (Condition), Jaminan (Collateral). Analisa 5P mencakup faktor Kepribadian (Personality), Tujuan (Purpose), Potensi (Prospect), Pembayaran (Payment), Golongan (Party). ${ }^{58}$ Pada dasarnya, motode analisis kredit bank dapat diterapkan dalam penyelengggaraan P2PL, walaupun penerapan analisis dimaksud tidak sepenuhnya dilakukan dengan cara yang sama.

Analisis kredit di bidang perbankanbertujuan agar keputusan pemberian kredit oleh bank dilakukan secara tepat untuk mencegah kredit bermasalah. ${ }^{59}$ Khusus di bidang perbankan, terdapat peraturan khusus mengenai ambang batas

\footnotetext{
${ }^{55}$ Lampiran IV Surat Edaran OJK Nomor 50/SEOJK.03/2017 tentang Pelaporan dan Permintaan Informasi Debitur Melalui Sistem Layanan Informasi Keuangan.

${ }^{56}$ Ibid.

${ }^{57}$ Ibid.

${ }^{58}$ Djoni S Gazali, dan Rachmadi Usman, Hukum Perbankan, Jakarta, Sinar Grafika, 2010, hlm. 273-274

${ }^{59}$ Supriyono R, Akuntansi Biaya, Perencanaan dan Pengendalian Biaya, Serta Pengambilan Keputusan, Yogyakarta, BPFE, 2011, hlm. 161
} 
maksimal NPL dan implikasi hukum terhadap suatu bank dengan nilai NPL yang melebihi ambang batas. Hal demikian sebagaimana duatur dalam Peraturan OJK No.15/POJK.03/2017 tentang Penetapan Status Dan Tindak Lanjut Pengawasan Bank Umum (POJK No.15/POJK.03/2017). Rasio kredit bermasalah secara neto (NPL net) atau rasio pembiayaan bermasalah secara neto (Non Performing Financing/NPF net) adalah sebesar lebih dari 5\% dari total kredit atau total pembiayaan.

Pengaturan mengenai ambang batas NPL, beserta implikasi hukumnya, tidak terdapat di dalam penyelenggaraan P2PL. Belum ada peraturan yang secara khusus mengatur tentang ambang batas NPL dan status penyelenggara P2PL dengan tingkat pinjaman bermasalahyang tinggi.

Selain kedua POJK di atas, substansi pengaturan mitigasi risiko juga terdapat di dalam POJK No.13/POJK.02/2018. Inovasi Keuangan Digital (IKD) adalah aktivitas pembaruan proses bisnis, model bisnis, dan instrumen keuangan yang memberikan nilai tambah baru di sektor jasa keuangan dengan melibatkan ekosistem digital.60 P2PL merupakan salah satu bentuk dari IKD yang berkembang di Indonesia. Otoritas menyadari bahwa banyak risiko yang mengancam masyarakat dengan berkembangnya IKD. Risiko tersebut dapat meliputi risiko bisnis, risiko hukum, dan risiko teknologi informasi. ${ }^{61}$

Oleh karena itu, untuk mencegah risiko-risiko tersebut terjadi, OJK mewajibkan penyelenggara IKD untuk menerapkan prinsip pemantauan secara mandiri. ${ }^{62}$ Pengaturan tersebut menunjukan bahwa dalam melakukan IKD, setiap penyelenggara harus tetap memperhatikan aspek perlindungan konsumen, terutama dengan penerapan prinsip manajemen risiko (risk management) dan kehati-hatian (prudential).

Pasal 18 ayat (2) POJK No.13/POJK.02/2018 selanjutnya menentukan bahwa untuk melaksanakan pemantauan, penyelenggara wajib menginventarisasi risiko utama yang paling sedikitmencakup risiko strategis, risiko operasional sistemik,

\footnotetext{
${ }_{60}$ Pasal 1 Angka 1POJK No 13/POJK.02/2018 tentang Inovasi Keuangan Digital di Sektor Jasa Keuangan

${ }^{61}$ Ricky Pratomo, "Aturan dan Risiko Bisnis Inovasi Keuangan Digital”, https://www.hukumonline.com/klinik/detail/ulasan/lt5bc6c2234e31c/aturan-dan-risiko-bisnis-inovasikeuangan-digital/ diakses pada 3 April 2020.

62Pasal 18 ayat (1) POJK No 13/POJK.02/2018
} 
risiko operasional individual, risiko pencucian uang dan pendanaan terorisme, risiko perlindungan data konsumen,risiko penggunaan jasa pihak ketiga, risiko siber, serta risiko likuiditas.

Selain terdapat di dalam POJK, substansi kewajiban mitigasi risiko juga terdapat di dalam PBI No.19/12/PBI/2017. Dalam PBI dimaksud, teknologi finansial adalah penggunaan teknologi dalam sistem keuangan yang menghasilkan produk, layanan, teknologi, dan/atau model bisnis baru serta dapat berdampak pada stabilitas moneter, stabilitas sistem keuangan, dan/atau efisiensi, kelancaran, keamanan, dan keandalan sistem pembayaran. 63

Pasal 3 ayat (1) PBI No.19/12/PBI/2017 menentukan bahwa penyelenggaraan teknologi finansial dikategorikan ke dalam sistem pembayaran, pendukung pasar, manajemen investasi dan manajemen risiko, pinjaman, pembiayaan, dan penyediaan modal, serta jasa finansial lainnya. Penjelasan Pasal 3 ayat (1) huruf d PBI No 19/12/PBI/2017 selanjutnya mencontohkan yang dimaksud dengan penyelenggaraan teknologi finansial pada kategori pinjaman (lending), pembiayaan (financing atau funding), dan penyediaan modal (capital raising) antara lain layanan pinjam meminjam uang berbasis teknologi informasi (P2PL).

Ketentuan selanjutnya yang berkaitan dengan mitigasi risiko P2PL dapat dilihat pada Pasal 8 ayat (1) huruf c PBI No.19/12/PBI/2017. Pasal tersebut mengatur bahwa penyelenggara teknologi finansial yang telah terdaftar di Bank Indonesia wajib menerapkan prinsip manajemen risiko dan kehati-hatian. Penjelasan Pasal 8 ayat (1) huruf cmenerangkan bahwa yang dimaksud "menerapkan prinsip manajemen risiko" adalah penyelenggara teknologi finansial wajib melakukan identifikasi, pengukuran, pemantauan, dan pengendalian atas risiko yang mungkin timbul dalam kegiatan usahanya.

Belum adanya aturan khusus mengenai kewajiban mitigasi risiko khususnya risiko pinjaman bermasalah, ambang batas rasio NPL, serta implikasi hukum bagi penyelenggara P2PL dengan NPL tinggi mengakibatkan persoalan hukum tersendiri. Persoalan hukum dimaksud berkaitan dengan kepastian dan

${ }^{63}$ Pasal 1 angka 1 PBI No 19/12/PBI/2017 
perlindungan hukum bagi para pihak. Dalam konteks pinjaman bermasalah yang berujung pada pinjaman macet, pihak yang paling dirugikan adalah pemberi pinjaman (investor). Oleh karena itu, perlindungan hukum terhadap dana milik investor menjadi persoalan krusial tersendiri dalam penyelenggaraan P2PL.

\section{Penerapan Mitigasi Risiko Pinjaman Bermasalah oleh Perusahaan Penyelenggara Peer to Peer Lending di Indonesia}

Mekanisme P2PL melibatkan tiga pihak yakni investor selaku kreditor, peminjam selaku debitor serta perusahaan penyelenggara selaku pihak yang menyediakan market place (teknologi yang mempertemukan kreditor dengan debitor). Secara sederhana mekanisme P2PL nampak dalam bagan berikut ini:64

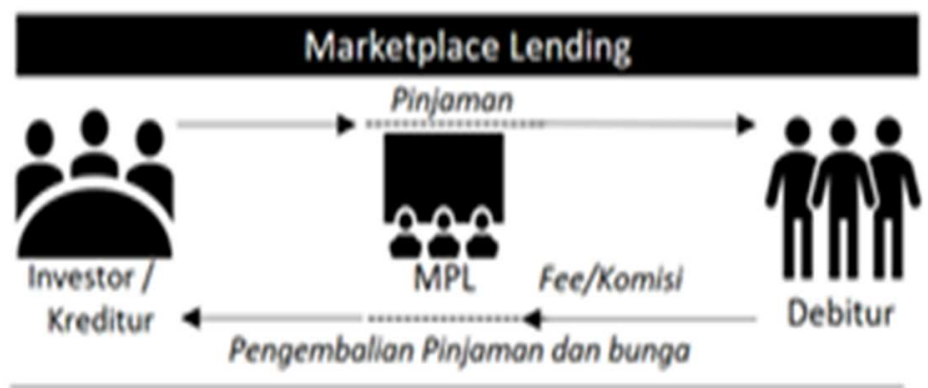

Berdasarkan bagan di atas jelas bahwa pihak kreditor dan debitor dalam mekanisme P2PL dipertemukan melalui sebuah market place yang disediakan dan dikelola oleh perusahaan penyelenggara. Oleh karena itu, ketika penerima pinjaman tidak membayar pinjaman dengan berbagai alasan, maka yang dirugikan ialah pemberi pinjaman dan pihak penyelenggara. Sehingga perlu adanya mitigasi risiko untuk mencegah adanya pinjaman bermasalah.

Mitigasi risiko adalah segala upaya yang dilakukan dalam rangka mencegah timbulnya berbagai risiko dalam penyelenggaraan P2PL. Risiko yang menjadi fokus dalam penelitian ini yaitu risiko pinjaman bermasalah atau NPL. Pinjaman bermasalah pada P2PL tidak jauh berbeda dengan kredit macet pada industri perbankan.

Menurut Hariyani, pinjaman bermasalah dapat disebabkan oleh faktor internal dan eksternal. Faktor internal penyebab pinjaman bermasalah yaitu kebijakan perkreditan yang ekspansif, menyimpang dalam pelaksanaan prosedur

${ }^{64}$ Inda Rahadiyan, Op. Cit. 
perkreditan, pemilik tidak beritikad baik, pengurus atau pegawai bank, dan/atau lemahnya sistem informasi pinjaman bermasalah. ${ }^{65}$ Sedangkan faktor eksternal yaitu faktor yang berada diluar bank dan debitor. Misalnya, kegagalan usaha debitor, pemanfaatan iklim persaingan perbankan yang tidak sehat oleh debitur, serta menurunnya kegiatan ekonomi dan tingginya suku bunga kredit. Hal ini mencakup keadaan makroekonomi, baik kondisi makroekonomi domestik maupun non-domestik. Hal ini juga dapat dikarenakan oleh laju pertumbuhan ekonomi pada saat penyaluran kredit tidak stabil seperti pelemahan kinerja ekspor dan kenaikan nilai tukar rupiah terhadap dollarAmerika Serikat.66

Pengaturan terkait mitigasi risiko dalam mekanisme P2PL di Indonesia sebagaimana telah dijelaskan sebelumnya memang belum diatur melalui peraturan khusus. Meskipun begitu, penerapan mitigasi risiko tetap merupakan suatu kewajiban yang harus dilaksanakan oleh penyelengga dan pengguna, sesuai Pasal 21 POJK No.77/POJK.01/2016. Selain itu, jika merujuk pada pemberian kredit di perbankan, maka dapat dilakukan analisis kredit dengan prinsip 5C dan 5P. Namun, pada mekanisme P2PL, tidak ada istilah analisis kredit layaknya di bidang perbankan. Oleh karena tidak adanya peraturan yang spesifik, setiap P2PL memiliki caranya masing-masing dalam melakukan mitigasi risiko untuk mencegah pinjaman bermasalah.

Mitigasi risiko yang dilakukan pada fase sebelum kredit dalam mekanisme P2PL dilakukan dengan cara melakukan penilaian karakteristik debitor. Penelitian ini akan berfokus pada penerapan mitigasi risiko untuk mencegah terjadinya pinjaman bermasalah pada P2PL Toko Modal, Investree, Dana Cita, dan Modal Rakyat, penjelasan lebih rinci akan diuraikan dalam tabel berikut :

${ }^{65}$ Andi Nursyahriana, et.all., "Analisis Faktor Penyebab Terjadinya Kredit Macet”,Forum Ekonomi, Vol.19, No.1, 2017, h.2. http://journal.feb.unmul.ac.id/index.php/FORUMEKONOMI diakses pada 15 Januari 2020.

${ }^{66} \mathrm{Ibid}$. Korelasi pinjaman bermasalah dengan melemahnya rupiah terhadap dolar dapat dibaca lebih lanjut : CNBC, Rupiah Melemah Lawan Dolar AS, Bank Untung Sekaligus Buntung, https:/ /www.cnbcindonesia.com/market/20180903083011-17-31394/rupiah-melemah-lawan-dolar-as-bankuntung-sekaligus-buntung ; CNBC, OJK: Dolar Menguat, Bank Perlu Waspadai Kenaikan Kredit Macet, https://www.cnbcindonesia.com/market/20180518114129-17-15501/ojk-dolar-menguat-bank-perlu-waspadaikenaikan-kredit-macet ; Kontan.co.id, Rupiah terus melemah, Kredit Macet Valas Rawan Naik, https://keuangan.kontan.co.id/news/rupiah-terus-melemah-kredit-macet-valas-rawan-naik ; Republika.co.id, Rupiah Melemah, Perbankan Harus Wredit Macet, https:/ /republika.co.id/berita/ekonomi/keuangan/18/09/05/pel5v3383-rupiah-melemah-perbankan-haruswaspadai-kredit-macet diakses pada 10 April 2020. 
Tabel: Penerapan Mitigasi Risiko Kredit pada Empat Perusahaan

Penyelenggara P2PL di Indonesia ${ }^{67}$

\begin{tabular}{|c|c|c|}
\hline No & $\begin{array}{l}\text { Penyelenggara } \\
\text { P2PL }\end{array}$ & Penerapan Mitigasi Risiko \\
\hline 1. & Investree ${ }^{68}$ & $\begin{array}{l}\text { 1. Memberikan informasi terkait syarat-syarat menjadi } \\
\text { pemodal dan peminjam. } \\
\text { 2. Investree mengimbau pemodal untuk } \\
\text { mempertimbangkan berbagaimacam risiko yang } \\
\text { diprediksi dapat terjadi sebelum memberikan pinjaman } \\
\text { melalui platform Investree. } \\
\text { 3. Investree memiliki sistem mitigasi risiko berupa credit- } \\
\text { scoring yang akurat, tim penilai kredit yang kompeten, } \\
\text { credit grading yang lengkap sebagai layanan tanpa } \\
\text { agunan dan hanya akan memberikan pinjaman kepada } \\
\text { badan atau perorangan yang memiliki tingkat kelayakan } \\
\text { kredit yang baik. } \\
\text { 4. Investree mengingatkan penguna bahwa level akurasi } \\
\text { dari credit-scoring dan grading yang digunakan juga tidak } \\
\text { dapat merefleksikan kondisi dan karakter kredit } \\
\text { peminjam secara utuh. } \\
\text { 5. Investree mencantumkan desclaimer risiko sebagai bahan } \\
\text { pertimbangan Penguna dalam memutuskan pengunaan } \\
\text { sistem P2PL. }\end{array}$ \\
\hline 2. & Toko Modal69 & $\begin{array}{l}\text { 1. Memberikan informasi terkait syarat-syarat menjadi } \\
\text { Pemodal dan Peminjam beserta tata caranya. } \\
\text { 2. Toko Modal memberikan asuransi terhadap pinjaman } \\
\text { bermasalah yaitu dengan melakukan pengembalian } \\
\text { senilai } 70 \% \text { dari nominal pinjaman bermasalah. } \\
\text { 3. Mencantumkan desclaimer risiko sebagai bahan } \\
\text { pertimbangan Penguna dalam memutuskan pengunaan } \\
\text { sistem P2PL. }\end{array}$ \\
\hline 3. & Modal Rakyat ${ }^{70}$ & $\begin{array}{l}\text { 1. Memberikan informasi terkait syarat-syarat menjadi } \\
\text { Pemodal dan Peminjam beserta tata caranya. } \\
\text { 2. Melakukan credit scoring dan menyeleksi UMKM } \\
\text { melalui penilaian, serta pengumpulan data atau survey. } \\
\text { Modal Rakyat juga mengembangkan teknologi } \\
\text { penilaian kredit dan analisis risikonya sendiri, } \\
\text { meskipun informasi terkait mekanisme analisis } \\
\text { kreditnya tidak disebarluaskan melalui Website. } \\
\text { 3. Modal Rakyat juga melakukan pengecekan terhadap } \\
\text { usaha UMKM serta laporan keuangan UMKM. }\end{array}$ \\
\hline
\end{tabular}

${ }^{67}$ Sumber : diolah, Penulis, 2019.

${ }^{68} \mathrm{https}: / /$ www.investree.id/ diakses pada 20 Oktober 2019.

${ }^{69} \mathrm{https}: / /$ tokomodal.co.iddiakses pada 20 Oktober 2019.

${ }^{70} \mathrm{https} / / /$ www.modalrakyat.iddiakses pada 20 Oktober 2019. 


\begin{aligned} \hline 4. & Mencantumkan desclaimer risiko sebagai bahan \\ & pertimbangan Penguna dalam memutuskan pengunaan \\ & sistem P2PL. \\ 4. Dana Cita ${ }^{71} \quad$ 1. & Memberikan informasi terkait syarat-syarat menjadi \\ & Pemodal dan Peminjam beserta tata caranya, kemudian \\ & dilakukan verifikasi terhadap setiap dokumen \\ & persyaratan yang diupload. \\ 2. & Adanya penjamin sebagai syarat pengajuan pinjaman \\ & untuk menjamin proses pinjam meminjam berjalan \\ & lancar. \\ 3. & Himbauan bahwa kelancaran pinjaman oleh setiap \\ & peminjam akan menentukan penilaian Dana Cita \\ & terhadap peminjam jika mengajukan pinjaman di waktu \\ & yang akan datang. \\ 4. & Mencantumkan desclaimer risiko sebagai bahan \\ & pertimbangan Penguna dalam memutuskan pengunaan \\ & sistem P2PL. \end{aligned}

\section{Penutup}

Perihal mitigasi risiko pinjaman bermasalah dalam Penyelenggaraan P2PL belum diatur secara khusus di Indonesia. Pengaturan mitigasi risiko guna mencegah pinjaman bermasalah dalam P2PL masih tersebar di berbagai peraturan. Peraturan dimaksud meliputi: Peraturan Otoritas Jasa Keuangan Nomor 77/POJK.01/2016 tentang Layanan Pinjam Meminjam Uang Berbasis Teknologi Informasi; Peraturan Otoritas Jasa Keuangan Nomor 18/POJK.03/2017 tentang Pelaporan dan Permintaan Informasi Debitor Melalui Sistem Layanan Informasi Keuangan; Peraturan Otoritas Jasa Keuangan Nomor 13/POJK.02/2018 tentang Inovasi Keuangan Digital di Sektor Jasa Keuangan; dan Peraturan Bank Indonesia Nomor 19/12/PBI/2017 tentang Penyelenggaraan Teknologi Finansial. Selain belum adanya pengaturan khusus mengenai mitigasi risiko pinjaman bermasalah, belum ada pula pengaturan mengenai ambang batas maksimum NPL. Kondisi demikian berakibat pada lemahnya kepastian hukum serta perlindungan hukum.

Masing-masing penyelenggara P2PL pada tataran praktik menetapkan kebijakan internal dalam rangka memitigasi risiko pinjaman bermasalah yang berpotensi menjadi pinjaman macet. Beberapa diantara penerapan mitigasi

${ }^{71}$ https://danacita.co.id/faq diakses pada 20 Oktober 2019. 
dimaksud sebagaimana dilaksanakan oleh Investree, Toko Modal, Modal Rakyat, serta Dana Cita.

Berdasar pada realitas pengaturan dan penerapan mitigasi risiko sebagaimana diuraikan, penulis ingin menyampaikan dua saran. Pertama, agar OJK dapat menyusun peraturan khusus tentang mitigasi risiko khusus pinjaman bermasalah dalam penyelenggaraan P2PL. Peraturan khusus dalam konteks ini menjadi sangat penting guna memberikan kepastian dan perlindungan hukum khususnya bagi pihak pemberi pinjaman. Dari perspektif penyelenggara, peraturan khusus dimaksud juga bermanfaat guna memberikan standar yang sama bagi tata cara penerapan mitigasi risiko NPL. Kedua, agar setiap perusahaan penyelenggara senantiasa melakukan pemantauan dan review terhadap kebijakan mitigasi risiko NPL. Setiap perusahaan penyelenggara P2PL seyogyanya dapat melaksanakan keterbukaan informasi terhadap rasio NPL dan upaya yang dilakukan guna menyelesaiakan pinjaman macet.

\section{Daftar Pustaka}

\section{Buku}

D.W., Arner. Barberis, J., and Buckley, R.P, The Evolution of Fintech: A New PostCrises Paradigm, University of Hongkong, Hongkong, 2015.

Gazali, Djoni S. dan Rachmadi Usman, Hukum Perbankan, Sinar Grafika, Jakarta, 2016.

Marzuki, Peter Mahmud, Penelitian Hukum, Kencana Prenada Media Group, Jakarta, 2017.

Muhammad, Abdulkadir Hukum dan Penelitian Hukum, PT. Citra Aditya Bakti, Bandung, 2004.

R, Supriyono, Akuntansi Biaya, Perencanaan dan Pengendalian Biaya, Serta Pengambilan Keputusan, BPFE,Yogyakarta, 2011.

Tim Penulisan Pedoman Tugas Akhir, Pedoman Penulisan Tugas Akhir Program Studi S1 Ilmu Hukum, Cetakan Kedua, FH UII Press, Yogyakarta, 2016.

\section{Jurnal, Laporan Penelitian serta Makalah Seminar}

Chaffee, Eric C. and Geoffrey C. Rapp, "Regulating Online Peer-to-Peer Lending in the Aftermath of Dodd-Frank: In Search of an Evolving Regulatory Regime for an Evolving Industry",Washington and Lee Review, Vol.69, Issue 2, Article 4, 2012. 
Darman, "Financial Technology (Fintech): Karakteristik dan Kualitas Pinjaman pada Peer to Peer Lending di Indonesia",Jurnal Manajemen Teknologi, Vol. 18, No. 2, 2019

M., Aaron, Rivadeneyra, F., and Sohal, S, "Fintech: Is this time different?A framework for Assessing Risks and Opportunities for Central Banks?",Bank of Canada Staff Discussion Paper 2017-10 (July), Canada: Bank of Canada, 2017

Nursyahriana, Andi, dkk, "Analisis Faktor Penyebab Terjadinya Kredit Macet,"Forum Ekonomi, Vol.19, No.1, 2017. dapat diakses melalui http://journal.feb.unmul.ac.id/index.php/FORUMEKONOMI diakses pada 15 Januari 2020

Rahadiyan, Inda,"Aspek Hukum dan Tantangan Pengaturan Peer to Peer Lending di Indonesia", Materi Presentasi Seminar Nasional "Implementasi dan Tantangan Fintech Lending di Indonesia", Diselenggarakan atas kerjasama Otoritas Jasa Keuangan Republik Indonesia dan Business Law Community Fakultas Hukum Universitas Gadjah Mada, 22 September 2018.

Passagi, Hendrikus, “Fintech Lending Indonesia Pendanaan Gotong Royong Online", Materi Seminar Nasional "Implementasi dan Tantangan Fintech Lending di Indonesia, Kerjasama antara Business Law Community Fakultas Hukum UGM dengan Otoritas Jasa Keuangan Republik Indonesia, Yogyakarta 22 September 2018

Usanti, Trisadini P. dan Fiska Silvia R.R, "Legal Protection of the Contracting Parties in The Peer to Peer Lending Based on Finacial Technology (P2P Lending Fintech) in Indonesia," Advances in Social Science, Education and Humanities Research (ASSEHR), Vol.131, Interntional Conference on Law, Governance and Globlzation 2017 (ICLGG 2017), Atlantis Press, 2017.

Verstein, Andrew, “The Misregulation of Person-to-Person Lending”, University of California, Davis, Vo.45:445, 2011.

Yang, Jianhui, et.all, "Research on P2P Credit Risk Assessment Model Based on RBM Feature Extraction- Take SME Customers as an Example", Open Journal of Business and Management, Scientific Research Publishing, Aug 7, 2019, dapat diakses melaluiDOI: 10.4236/ojbm.2019.74107 diakses pada 15 Januari 2020

\section{Majalah dan Buletin}

Nizar, Muhammad Afdi,Teknologi Keuangan (Fintech): Konsep dan Implementasinya Di Indonesia, Warta Fiskal Kementrian Keuangan Republik Indonesia, Edisi 5, 2017

\section{Peraturan Perundang-Undangan}

Undang-Undang Nomor 19 Tahun 2016 tentang Perubahan Atas Undang-Undang Nomor 11 Tahun 2008 tentang Informasi dan Transaksi Elektronik 
Peraturan Pemerintah Nomor 71 Tahun 2019 tentang Penyelenggaraan Sistem dan Transaksi Eletronik

Peraturan Otoritas Jasa Keuangan Nomor 77/POJK.01/2016 tentang Layanan Pinjam Meminjam Uang Berbasis Teknologi Informasi

Peraturan Otoritas Jasa Keuangan Nomor 18/POJK.03/2017 tentang Pelaporan dan Permintaan Informasi Debitor Melalui Sistem Layanan Informasi Keuangan

Peraturan Otoritas Jasa Keuangan Nomor 13/POJK.02/2018 tentang Inovasi Keuangan Digital di Sektor Jasa Keuangan

Peraturan Bank Indonesia Nomor 19/12/PBI/2017 tentang Penyelenggaraan Teknologi Finansial

Lampiran IV Surat Edaran OJK Nomor 50/SEOJK.03/2017 tentang Pelaporan dan Permintaan Informasi Debitur Melalui Sistem Layanan Informasi Keuangan

\section{Internet}

Antaranews, "OJK: Indeks Literasi dan Inklusi Keuangan Meningkat", https://www.antaranews.com/berita/1152836/survei-ojk-indeks-

literasi-dan-inklusi-keuangan-meningkat diakses 30 Desember 2019diakses pada 10 April 2020.

Bisnis.com, "Minat Fintech Melesat Akibat Lemahnya Perbankan", https:/ / finansial.bisnis.com/read/20190724/89/1127973/minat-fintechmelesat-akibat-lemahnya-perbankan diakses pada 15 Januari 2020

CNBC, "Rupiah Melemah Lawan Dolar AS, Bank Untung Sekaligus Buntung", https: / / www.cnbcindonesia.com/market/20180903083011-17-

31394/rupiah-melemah-lawan-dolar-as-bank-untung-sekaligus-buntung diakses pada 10 April 2020

CNBC, "OJK: Dolar Menguat, Bank Perlu Waspadai Kenaikan Kredit Macet", https:/ / www.cnbcindonesia.com/market/20180518114129-17-15501/ojkdolar-menguat-bank-perlu-waspadai-kenaikan-kredit-macetdiakses pada 10 April 2020.

David, Kevin et.all, "Catching-Up with Indonesia's Fintech Industry", Working Paper, Australian Centre for Financial Studies Monash Univesity, May 2017, https://australiancentre.com.au/wp-content/uploads/2017/05/

2_Catching-Up-with-Indonesias-Fintech-Industry.pdf diakses 30 Desember 2019

Hadad, Muliaman D. "Financial Technology di Indonesia", Presentasi Kuliah Umum tentang Fintecht, IBS, 2017, http://www.ibs.ac.id/img/doc/ MDH\%20-\%20FinTech\%20IBS\%20June\%202017.pdf diakses pada 10 September 2019 
Kontan.co.id, "Rupiah terus melemah, Kredit Macet Valas Rawan Naik", https:/ / keuangan.kontan.co.id/news/rupiah-terus-melemah-kreditmacet-valas-rawan-naikdiakses pada 10 April 2020.

Kontan.co.id, "OJK Targetkan NPL Fintech Lending di bawah 1\%", https:/ / keuangan.kontan.co.id/news/ojk-targetkan-npl-fintech-lendingdi-bawah-1-hingga-akhir-2018 diakses 30 Desember 2019

Omarini, Eugenia, "A Peer-to-Peer Lending: Business Model Analysis and the Platform Dilemma", International Journal of Finance, Economics, and Trade (IJFET), Research Article, 2018;2(3), diakses melalui https: / / www.semanticscholar.org/paper/Peer-to-peer-lending\%3Abusiness-model-analysis-and-

Omarini/e20dcad9663332f271397ec0471caf329130514c diakses pada 18 Januari 2020

OJK, "Otoritas Jasa Keuangan, Kanal IKNB: Data dan Statistik Fintech", https://www.ojk.go.id/id/kanal/iknb/data-dan_statistik/fintech/ Documents/Statistik\%20Oktober\%202019.pdfdiakses 30 Desember 2019

OJK, "Statisik Fintech Lending Periode November 2019", https:/ /www.ojk.go.id/ $\mathrm{id} / \mathrm{kanal} / \mathrm{iknb} /$ data-dan-statistik/fintech/Pages/Statistik-FintechLending-Periode-November-2019.aspxdiakses pada 10 Januari 2020.

OJK, "Ikhtisar Data Keuangan (Peer to Peer Lending) Desember 2018", https: / www.ojk.go.id/id/kanal/iknb/data-danstatistik/fintech/Pages/Ikhtisar-Data-Keuangan-Fintech-(Peer-To-PeerLending)-Periode-Desember-2018.aspx

OJK, "Perkembangan Fintech Lending Periode Desember 2019", https://www.ojk.go.id/id/kanal/iknb/data-danstatistik/fintech/Pages/Statistik-Fintech-Lending-Periode-Desember2019.aspx diakses pada 13 April 2020.

Republika.co.id, "Rupiah Melemah, Perbankan Harus Waspadai Kredit Macet", https://republika.co.id/berita/ekonomi/keuangan/18/09/05/pel5v3383 -rupiah-melemah-perbankan-harus-waspadai-kredit-macet diakses pada 10 April 2020.

Pratomo, Ricky,"Aturan dan Risiko Bisnis Inovasi Keuangan Digital", https://www.hukumonline.com/klinik/detail/ulasan/lt5bc6c2234e31c/atu ran-dan-risiko-bisnis-inovasi-keuangan-digital/ diakses pada 3 April 2020.

https: / / www.investree.id/ diakses pada 20 Oktober 2019

https: / / tokomodal.co.iddiakses pada 20 Oktober 2019

https: / / www.modalrakyat.iddiakses pada 20 Oktober 2019

https: / / danacita.co.id/faq diakses pada 20 Oktober 2019 